\title{
Konsep Cinta Pada Puisi-Puisi Karya Sapardi Djoko Damono: Analisis Semiotika Carles Sanders Pierce
}

\author{
Ika Mustika $^{1}$, Heri Isnaini ${ }^{1}$ \\ ${ }^{1}$ Program studi Pendidikan Bahasa dan Sastra Indonesia, Institut Keguruan dan Ilmu Pendidikan Siliwangi \\ Jalan Terusan Jenderal Sudirman, Cimahi, Jawa Barat
}

Penulis untuk Korespondensi/E-mail: mestikasaja@ikipsiliwangi.ac.id

\begin{abstract}
This article discusses the concept of love in poems by Sapardi Djoko Damono. The concept of love as expressed by Erich Fromm is the answer to the problem of human existence. The concept of universal love can be seen as the art of life which includes: human love for man, human love for nature, and human love for god. The problems that arise in this article are: how the concept of love is presented in poems by Sapardi Djoko Damono; and how the meaning of the concept of love is seen from the use of signs in poetry. Based on these problems, the concept of love will be discussed on the strength of the sign present in the poem. The signs are then analyzed based on the semiotics theory presented by Pierce, namely by observing representatives, objects, and interpretants. This article also shows the mark's relationship with other texts and their use of language styles. The discussions then boil down to the meaning of the concept of love contained in the poems by Sapardi Djoko Damono. Finally, the meaning of this concept of love can be seen as a universal concept that refers to human existence as a form of existence in the world. The results of this study showed that the concept of love in the poems of Sapardi Djoko Damono was found in the level of diction, imagery, and language style. The concept of love found at the level of the structure becomes an important part of understanding the poem as a whole and interpreting the poems.
\end{abstract}

Abstark - Artikel ini membahas konsep cinta pada puisi-puisi karya Sapardi Djoko Damono. Konsep cinta seperti yang dikemukakan oleh Erich Fromm merupakan jawaban atas masalah pada eksistensi manusia. Konsep cinta yang universal dapat dilihat sebagai seni kehidupan (art of life) yang meliputi: cinta manusia kepada manusia, cinta manusia kepada alam, dan cinta manusia kepada tuhan. Masalah yang muncul dalam artikel ini adalah: bagaimana konsep cinta direpresentasi dalam puisi-puisi karya Sapardi Djoko Damono; serta bagaimana pemaknaan konsep cinta tersebut dilihat dari penggunaan tanda-tanda di dalam puisi. Berdasarkan permasalahan tersebut, konsep cinta akan dibahas pada kekuatan tanda yang hadir di dalam puisi. Tanda-tanda tersebut kemudian dianalisis berdasarkan teori semiotika yang dikemukakan oleh Pierce, yakni dengan memperhatikan representament, object, dan interpretant. Di samping itu, artikel ini juga menunjukkan hubungan (relasi) tanda dengan teks lain dan penggunaan gaya bahasanya. Pembahasan-pembahasannya kemudian bermuara pada pemaknaan konsep cinta yang terdapat pada puisi-puisi karya Sapardi Djoko Damono. Akhirnya, pemaknaan konsep cinta ini dapat dilihat sebagai konsep universal yang merujuk pada keperiadaan manusia sebagai bentuk eksistensinya di dunia. Hasil penelitian ini menunjukkan bahwa konsep cinta pada puisi-puisi Sapardi Djoko Damono ditemukan dalam tataran diksi, citraan, dan gaya bahasa. Konsep cinta yang ditemukan pada tataran struktur tersebut menjadi bagian penting dalam memahami puisi secara keseluruhan dan memaknai puisi-puisi tersebut.

Keywords - Concepts of love, Semiotics, Intertextuality, Stilistika, Poetry 


\section{PENDAHULUAN}

A rtikel ini diawali dengan argumentasi adanya gap dan relevansi atas penelitian-penelitian sebelumnya yang membahas tentang puisi-puisi Sapardi Djoko Damono dalam berbagai perpektif dan pendekatan. Ridha Al Qadri [1] dengan penelitian yang berjudul "Sapardi dan Tanda: Telaah Semiotik atas Kumpulan Puisi Kolam". Hasil penelitian tersebut Al Qadri memetakan tanda-tanda yang digunakan Sapardi Djoko Damono di dalam kumpulan puisi Kolam seperti penggunaan objek alam seperti diksi daun, kolam, burung, awan, angin, kabut, dan hujan. Tanda-tanda berikutnya adalah pemanfaatan makna simbolik dalam beberapa diksinya. Penelitian tersebut mencakup konsep-konsep alam yang digunakan dalam puisi-puisi Sapardi Djoko Damono dilihat pada tataran semiotika. Hasilnya, tanda-tanda yang hadir pada kumpulan puisi Kolam menunjukkan adanya konsistensi penggunaan tanda yang mengacu pada diksi-diksi alam.

Selain itu, penelitian Heri Isnaini [2] yang membahas Representasi Ideologi Jawa pada PuisiPuisi Karya Sapardi Djoko Damono melihat konsep ideologi Jawa yang secara implisit ada di dalam puisi-puisi Sapardi Djoko Damono. Hasil penelitian tersebut menunjukkan bahwa ada konsep lain yang tersembunyi di dalam puisi-puisi Sapardi Djoko Damono yang merepresentasi konsep ideologi Jawa. Pembahasan terkait dengan puisi-puisi Sapardi Djoko Damono pada artikel Heri Isnaini dkk [3] membahas tentang konsep Manunggaling Kawula Gusti pada puisi-puisi Sapardi Djoko Damono. Hasil penelitian ini menunjukkan kekuatan diksi pada puisi-puisi Sapardi Djoko Damono menunjukkan kekuatan terhdap konsep yang secara implisit termaktub di dalamnya.

Penjelasan tersebut menjadi dasar argumentasi tentang gap dan relevansi yang dibahas pada artikel ini. Konsep yang akan dibangun pada artikel ini adalah konsep cinta yang terdapat pada puisi-puisi karya Sapardi Djoko Damono. Konsep tersebut tersirat dalam struktur puisi sehingga puisi-puisi tersebut harus dianalisis dalam kaitannya sebagai teks dan sebagai ideologi. Artinya, teks puisi tidak akan terlepas dari ide-ide pengarangnya. Dengan demikian, artikel ini memiliki posisi di antara penelitian-penelitian sebelumnya, yakni adanya relevansi yang dibahas (struktur teks, tanda-tanda dalam puisi); serta gap penelitian (objek penelitian dan tataran konsep yang dibahas). Sebagai objek kajian, puisi adalah salah satu karya sastra yang bersifat prismatis. Artinya, memiliki keterbukaan pemaknaan yang cukup luas. Hirsch [4] menjelaskan bahwa perbedaan makna kata tidak dapat dihindari karena makna kata bukanlah hanya apa yang dikatakan pengarang, melainkan apa makna kata itu bagi pembaca yang peka. Penjelasan terkait pembaca yang peka adalah pada istilah "tafsir terbaik". Pemaknaan akan dapat menuju kepada keabsahan dan ketepatan tafsir ketika "tafsir terbaik" mengacu kepada makna pengarang dan makna kritikus.

Untuk menuju konsep tersebut, Hirsch [4] menawarkan konsep determinacy dan typification, kedua konsep ini menjadi jalan yang dapat dipertanggungjawabkan terkait dengan keabsahan dan ketepatan tafsiran puisi. Konsep determinacy mengacu kepada makna kata yang dapat diteruskan kepada orang lain. Artinya, kata harus minimal memiliki dwimakna (dapat bermakna sesuatu yang lain) dan memiliki identitas diri (makna sendiri). Keduanya akan menunjukkan bahwa makna kata dapat diwujudkan kembali dan dapat diteruskan kepada orang lain. Konsep typification mengarah kepada wujud dengan garis batas yang dapat menentukan sesuatu termasuk bagiannya atau tidak dan typification harus diungkap lebih dari satu contoh. Kedua konsep tersebut sebagai bagian dari upaya menunjukkan keabsahan interpretasi makna kata. Hal ini didasari oleh apa pun yang dikehendaki pengarang untuk disampaikannya dengan menggunakan simbol-simbol linguistik dan makna. Berdasarkan penjelasan tersebut, pemaknaan terhadap puisi-puisi Sapardi Djoko Damono dapat didasari keabsahan yang argumentatif.

Puisi sebagai teks adalah sebuah bangun struktur yang memiliki kekokohan antarunsur pembangunnya. Seperti yang dijelaskan oleh Jean Piaget [5] bahwa struktur merupakan sebuah sistem yang dibangun atas kaidah dan aturan yang memiliki peran-peran tertentu tanpa keluar dari batas-batasnya. Dengan demikian, berbicara mengenai puisi sebagai teks, tentu saja yang akan kita hadapi adalah puisi dengan konvensinya, yakni: tipografi, irama, citraan, diksi, majas, dan sebagainya. Hal ini dielaborasi oleh Sherien Sabbah dan Paramita Ayuningtyas [6] bahwa puisi juga akan memperhatikan unsur-unsur retoris yang bisa menarik perhatian pembaca terhadap ide utama puisi tersebut. Unsur retoris bisa muncul dalam bentuk repetisi, tripling dan paralelisme. Penggunaan unsur-unsur tersebut merupakan bagian dari usaha pengarang dalam rangka 
menegaskan atau mengeksplorasi ide-ide dan konsep yang akan disampaikan kepada pembaca.

Konsep dalam puisi dan teks karya sastra yang lain merupakan struktur dalam yang menurut I.A. Richard yang dijelaskan oleh Waluyo [7] sebagai unsur batin puisi yang terdiri atas: sense (tema), feeling (perasaan), tone (nada), dan intention (amanat). Unsur-unsur tersebut adalah unsur puisi yang cara menemukannya harus dengan "membedah" unsur-unsur luarnya, yakni dengan tanda-tanda yang muncul pada unsur luarnya. Hal ini juga berkaitan dengan cara apresiator mengapresiasi unsur-unsur di dalam puisi tersebut, yakni hasil usaha pembaca dalam mencari dan menemukan nilai hakiki puisi lewat pemahaman dan penafsiran sistematik yang dinyatakan dalam bentuk tertulis [8].

Konsep yang akan dibahas pada artikel ini adalah konsep cinta yang secara universal adalah konsep umum yang hampir dapat dimaknai oleh semua apresiator. Cinta seperti yang dijelaskan oleh Sabrina [9] harus memiliki tiga unsur utama, yaitu: keintiman, rasa ingin memperhatikan, dan kepercayaan. Cinta adalah kelekatan jiwa individu lain yang ditopang oleh perasaan saling mempertahankan sehingga keduanya saling mempercayai. Klasifikasi tersebut membawa kepada pemahaman bahwa cinta dapat bersemayam dengan perantara kepada objek tertentu. Objek inilah yang kemudian dapat dipahami sebagai cinta.

Erich Fromm [10] memiliki pendapat bahwa cinta adalah salah satu seni kehidupan (art of life), yakni kesadaran manusia akan rasa cinta kepada sesama manusia, alam, dan cinta kepada Tuhan. Cinta yang dimaksudkan oleh Fromm menjaadi bagian yang lebih universal daripada sekadar cinta kepada lawan jenis saja. Tujuan dari berlangsungnya cinta adalah untuk kehidupan manusia yang secara hakiki harus memelihara keseimbangan alam. Harmonisasi alam menjadi pertaruhan manusia sebagai makhluk yang diberi akal dan cinta.

Konsep cinta pada artikel ini akan memanfaatkan analisis semiotika yang dikemukakan oleh Pierce. Zoest [11] menjelaskan perihal semiotika sebagai salah satu cabang ilmu yang memaparkan tanda. Tanda-tanda dalam ilmu semiotika dibahas dalam kaitan dan relasinya dengan tanda yang lain. Artinya, tanda dan segala hal terkait dengan tanda, baik itu cara pengiriman dan penerimaan tanda akan memiliki arti dan makna.
Ferdinand de Saussure (1857-1913) dan Carles Sanders Pierce (1839-1914) adalah ahli semiotika yang dapat diacu dalam membahas produk tanda. Tanda-tanda yang hadir baik itu tanda visual maupun nonvisual menjadi bagian dari objek pembahsan semiotika. Analisis dalam penelitian ini akan menggunakan teori semiotika yang dikemukakan oleh Carles Sanders Pierce, menurut Pierce seperti yang dikemukakan oleh Zoest [11], ada tiga macam tanda menurut hubungan tanda dengan denotatumnya, yaitu ikon, indeks, dan simbol. Dan hubungan trilingual antara representament, interpretant, dan object.

Representament adalah unsur yang mewakili sesuatu. Sesuatu yang jelas tidak hadir sehingga harus diwakili oleh sesuatu yang lain yang disebut dengan tanda. Hubungan yang sangat konvensional antara tanda-tanda (penanda dan petanda) memungkinkan kita melihat berbagai kemungkinan makna yang terbuka yang membuka diri bagi berbagai interpretasi. Apa yang dikemukakan oleh tanda, apa saja yang diacunya atau yang ditunjukknya oleh Pierce disebut object [11] Adapun interpretant merupakan interpretasi dari tanda dan apa yang dikemukakan oleh tanda. Interpretasi ini sangat berkaitan dengan ground atau denotatumnya. Jadi, suatu tanda mengacu pada acuan yang dikerangkai oleh groundnya. Contoh tanda-tanda lalu lintas hanya berfungsi ketika berada di jalan raya, tanda tersebut tidak menjadi acuan manakala tidak berada di jalan raya.

Berdasarkan penjelasan di atas, artikel ini secara sederhana akan membahas tanda-tanda yang muncul dalam teks puisi karya Sapardi Djoko Damono yang memiliki argumentasi pada konsep cinta. Tanda-tanda tersebut kemudian akan dibahas dalam kaitannya dengan konsep semiotika dari Carles Sanders Pierce. Kemudian konsep-konsep cinta tersebut dikerangkai oleh konsep art of life dari Erich Fromm.

\section{METODE}

Korpus penelitian ini adalah puisi-puisi karya Sapardi Djoko Damono yang diindikasi dan diargumentasikan memiliki konsep cinta. Puisipuisi yang dibahas akan diambil dari beberapa antologi puisi karya Sapardi Djoko Damono. Pemilihan puisi didasarkan pada frekuensi tandatanda yang muncul, diksi yang secara lateral menunjukkan konsep cinta, dan kerangka cinta yang universal dalam pandangan Erich Fromm. 
Antologi yang menjadi korpus dalam penelitian ini adalah: DukaMu Abadi [12], Mata Pisau [13], Sihir Hujan [14], Perahu Kertas [15], Hujan Bulan Juni [16], dan Kolam [17].

Metode penelitian ini adalah kualitatif dengan menggunakan data penelitian berupa teks puisi. Adapun tahapan penelitian dapat dijelaskan sebagai berikut: pertama, pemilihan korpus penelitian dan data penelitian didasarkan pada frekuensi data, makna literal, dan kerangka konsep. Kedua, data diklasifikasi berdasarkan struktur teks: bentuk, diksi, citraan, dan gaya bahasa. Ketiga, data dibahas dengan menggunakan teori semiotika Carles Sanders Pierce. Keempat, konsep cinta dikerangkai dengan konsep cinta yang dikemukakan oleh Erich Fromm.

\section{HASIL DAN PEMBAHASAN}

Konsep cinta yang diusung pada puisi-puisi karya Sapardi Djoko Damono dapat dibahas berdasarkan klasifikasi cinta yang dikemukakan oleh Erich Fromm. Pembahasan mengenai hal tersebut adalah sebagai berikut. Pembahasan - pembahasan ini diawali dengan pembahasan struktur yang memuat tanda-tanda di dalam puisi. Tanda-tanda di dalam puisi kemudian dikerangkai pada konsep cinta yang dikemukakan oleh Erich Fromm.

Pembahasan struktur diawali dengan pembahasan bentuk puisi. Bentuk teks yang dibahas pada penelitian ini adalah bentuk puisi. Klasifikasi yang digunakan pada bagian ini adalah analisis bentuk puisi yang terdiri atas jumlah baris-barisnya, konvensi yang digunakan adalah klasifikasi penulisan Puisi Baru, yaitu bentuk puisi 2 baris sampai 14 baris (mulai dari distichon, terzina, quartrain, quint, sextet, septima, oktaf, dan soneta). Selain itu, pembahasan bentuk ini juga menggunakan klasifikasi yang dijelaskan oleh Umar Junus [7] yaitu: mantra, pantun dan syair, soneta, dan puisi bebas.

Bentuk yang dominan pada puisi-puisi Sapardi Djoko Damono adalah bentuk dengan 4 baris dalam tiap baitnya. Seperti pada puisi berikut.

\section{Mengalirlah, Sungai}

mengalirlah, sungai, tenang ke lautmu waktu tegak aku di sini dalam warna biru Siapa berkata: lihatlah cuaca bersiap. Kabut terdengar menuruni lembah waktu seorang sudah lupa menunggu

kabar pun sampai, angin tiba-tiba mengambang di atasmu

hanyutkan, sungai, beribu kata, lagu dan tanda mata yang tak sempat dialamatkan kepada Dunia [12]

Pola-pola 4 baris ini menunjukkan bahwa Damono setia menggunakan konvensi puisi yang berlaku umum pada saat itu. Penulisan tetap menggunakan pola 4 baris, walaupun puisi tersebut hanya 1 bait. Seperti pada puisi berikut.

\section{Angin Pagi}

merendah angin pagi yang dingin

Suara yang dingin

surya yang masih juga Hidup aliasnya

memijar, berpijar-pijar di antara bulu-bulu mata [12]

Kesetiaan pada penulisan puisi 4 baris terdapat juga pada puisi berikut.

\section{Dalam Doa: II}

saat tiada pun tiada

aku berjalan (tiada

gerakan, serasa

isarat) Kita pun bertemu

sepasang Tiada

tersuling (tiada

gerakan, serasa

nikmat): Sepi meninggi

[12: 35]

Kedua puisi tersebut menunjukkan bahwa Damono setia menggunakan pola penulisan 4 baris pada antologi ini. Dengan demikian, secara umum polapola penulisan 4 baris yang digunakan Damono menunjukkan eksistensi kepenyairan Damono di Indonesia tahun 70-an yang cenderung menggunakan pola-pola penulisan 4 baris dalam tiap bait. Berdasarkan pembahasan tersebut, bentuk-bentuk puisi karya Sapardi Djoko Damono menunjukkan bahwa bentuk-bentuk yang ajek terhadap pengungkapan tema puisi diwujudkan dengan bentuk puisi empat baris (quartrain).

Sementara itu, Penggunaan citraan (imagery) pada puisi-puisi Sapardi Djoko Damono tidak terlepas dari diksi-diksi yang digunakan, diksi dan citraan memiliki keterikatan yang erat. Pemilihan kata yang menjadi ciri khas puisi-puisi Damono yang cenderung imajis menunjukkan konsep citraan yang terintegrasi antara pemikiran, perasaan, dan kualitas 
intelektual. Bahkan, Mahayana [18] menjelaskan bahwa kata dalam puisi-puisi Damono menjadi perpaduan hubungan intelektual dan non-intelektual yang meruap pada desakan emosi, citraan dan rasa yang terwakili.

Citraan yang hadir pada puisi-puisi Damono diwakili oleh diksi-diksi yang tidak hanya menggambarkan peristiwa dan perasaan, tetapi lebih jauh masuk ke dalam pengalaman dan kenangan yang harus diwakilkan dengan kata-kata. Pada puisi "Sajak Cinta" yang terdapat pada antologi DukaMu Abadi dan Mata Jendela dapat dilihat citraan berkelindan dengan diksi-diksi yang imajis dan sederhana.

Anak adalah bukti bahwa kita pernah bercinta, pernah saling berbohong, saling mengkhianati diri, saling lebur. Hanya itukah?

Citraan yang tampak dominan pada puisi tersebut adalah feeling imagery, konsep citra perasaan sangat dominan pada puisi tersebut. Citraan perasaan ini ternyata tidak bisa berdiri sendiri, melainkan harus berpadu pada (meminjam pendapat Mahayana) citra intelektual karena citraan pada bait puisi tersebut tidak bisa lepas hanya dengan melihat feeling imagery, tapi tetap ada proses "mengernyitkan kening", berpikir, apalagi ditambah dengan kalimat tanya retoris, "Hanya itukah?”.

Sekarang masih harus setia

mendengarkan suara, apa pun juga

sampai tuli; masih harus memandang

beribu warna, sampai buta; masih harus

menjumlah serta mengurangi sederet panjang

angka-angka.

Bait tersebut menunjukkan citraan yang lebih kompleks. Artinya, berbagai citraan masuk dalam sebuah peristiwa. Citraan pendengaran, penglihatan, tindakan, dan perasaan berosmosis menjadi satu peristiwa yang jalin-menjalin dengan diksi yang sangat imajinatif. Dengan demikian, penggunaan citraan pada puisi-puisi Damono dapat dimaknai sebagai bagian penting yang tidak dapat dipisahkan dari diksi. Penggunaan citraan pada puisi-puisi Damono dikorelasi dengan dominasi citraan yang membangun tema artikel ini.

Berdasarkan struktur yang dibahas pada puisi-puisi karya Sapardi Djoko Damono tersebut dapat dipahami bahwa puisi-puisi tersebut secara struktur dapat memuat beberapa konsep yang mengacu kepada konsep dan gagasan yang lebih abstrak, salah satunya adalah gagasan cinta. Dengan menggunakan kerangka teori Erich Fromm tentang art of life maka pembahasan selanjutnya, puisipuisi Sapardi Djoko Damono akan dibahas pada tataran kerangka tersebut. Pembahasan ini akan dibagi menjadi konsep cinta sebagai berikut: cinta kepada manusia; cinta kepada alam; dan cinta kepada Tuhan.

\section{Cinta kepada Manusia}

Konsep cinta yang paling umum dan pernah dirasakan manusia adalah cinta kepada manusia, baik cinta kepada orang tua, saudara, dan lawan jenis. Cinta ini seringkali dimaknai sebagai cinta yang romantis. Secara umum, dalam puisi-puisi karya Sapardi Djoko Damono, konsep cinta ini digambarkan pada kisah Adam dan Hawa sebagai ikon dan simbol cinta manusia kepada manusia. Pada puisi "Hawa Dingin" Arloji [19] dan AyatAyat Api [20] penciptaan perempuan pertama, Hawa. Judul puisi ini sangat taksa, hawa dapat berarti udara, nafsu, dan nama "Hawa". Apakah judul tersebut menggambarkan Hawa yang (dalam kondisi) tidak bersemangat, atau udara yang dingin? Ketaksaan puisi ini menjadi menarik karena sosok Hawa dikisahkan adalah makhluk yang diciptakan dari tulang rusuk Adam. Apakah ini yang menyebabkan Hawa (menjadi) dingin. Berikut kutipan puisi "Hawa Dingin"

dingin malam memang tak pernah mau menegurmu, dan membiarkanmu telanjang; berdiri saja ia di sudut itu dan membentakku, "Ia hanya bayang-bayang!"

"Bukan, ia tulang rusukukku", sahutku sambil menyaksikannya mendadak menyebar ke seluruh kamar-yang tersisa tinggal abu sesudah kita berdua habis terbakar

[19]

Kisah penciptaan Hawa dari tulang rusuk Adam menjadi menarik karena menampilkan sosok manusia awal dalam penciptaan manusia oleh Tuhan. Proses penciptaan manusia pertama Adam dan Hawa seiring dengan puisi "Sonet: Hei! Jangan Kaupatahkan" dalam antologi DukaMu Abadi [12] dan Hujan Bulan Juni [16] diksi pada puisi tersebut adalah kuntum bunga, mekarlah, dan rahim alam. Bunga sebagai bagian dari diksi yang terdapat pada puisi tersebut menggambarkan sebagai makhluk yang baru dilahirkan. Dia mekar dari tanaman yang hidup dengan sehat. 
Hawa menjadi bagian penting dalam membahas cinta ini karena konsep cinta yang diajarkan Tuhan adalah ketika penciptaan Hawa dari tulang rusuk Adam. Artinya, Tuhan sudah membuat skema cinta antar manusia dengan sangat rinci dan teliti. Cinta hanya dimiliki oleh kedekatan (metafora tulang rusuk) dan cinta akan menemui pemiliknya tanpa tertukar. Pada puisi "Sajak Cinta" juga menyinggung masalah dosa pertama manusia, yakni buah apel. Apel disimbolkan sebagai bentuk larangan Tuhan yang dilanggar oleh Adam dan Hawa.

Anak adalah bukti bahwa kita pernah bercinta, pernah saling berbohong, saling mengkhianati diri, saling lebur

Sehabis kau makan

buah apel itu kau pun memberikan sebagian

untukku; aku, seperti lazimnya pahlawan-pahlawan besar,

menikmati sisa dosa itu.

Kisah Adam dan Hawa adalah kisah romantis, penuh cinta. Anak-anak adalah bukti bahwa pernah bercinta, melebur menjadi satu dengan berbagai macam emosi yang melingkupi. Intinya, saling mencinta. Oleh karena rasa cinta itu, Adam juga rela menanggung dosa pertama itu, demi Hawa. /aku seperti lazimnya pahlawan-pahlawan besar, menikmati sisa dosa itu/.

Kisah Adam dan Hawa juga digambarkan pada puisi "Angin, 1" dalam antologi Perahu Kertas [15] dan Mata Jendela [21]. Puisi tersebut bercerita

angin yang diciptakan untuk senantiasa bergerak dari sudut

ke sudut dunia ini pernah pada suatu hari berhenti ketika mendengar suara dari nabi kita Adam menyapa istrinya untuk pertama kali,

"hei siapa ini yang mendadak di depanku?"

angin itu tersentak kembali ketika

kemudian terdengar jerit

wanita untuk pertama kali, sejak itu ia terus bertiup tak pernah

menoleh lagi -

Ini proses kelahiran akan cinta: Adam dan Hawa, tema ini menyimbolkan sebagai sebuah awal dari perjalanan panjang manusia karena konsekuensi dari dosa yang dilakukan. Akan tetapi, dari kisah ini dapat disampaikan bahwa Tuhan telah menggariskan takdir manusia itu dengan sangat mudah, yakni dengan hanya mengucap kun fayakun (jadi, maka jadilah). Puisi-puisi tersebut secara tanda-tanda simbolik telah menjelaskan konsep cinta antar manusia.

\section{Cinta Kepada Alam}

Konsep cinta kepada alam adalah konsep cinta yang menempatkan manusia sebagai bagian dari penjaga alam dari kerusakan. Rasa memiliki alam sehingga tetap lestari adalah bagian dari konsep ini. Konsep menyeimbangkan alam dengan cara menjaga dan mempercantiknya berkaitan dengan keindahan alam dan harmonisasi di dalamnya. Pada puisi-puisi berikut konsep alam yang indah menjadi bagian yang tidak terpisahkan dalam konsep ini.

Diksi-diksi pada konsep cinta kepada alam menunjukkan keindahan alam dalam konsep keseimbangan dan harmonisasi mikrokosmos dan makrokosmos. Keindahan itu digambarkan dalam konteks alam dan konstelasinya dalam teks. Pada puisi "Ayat-Ayat Kyoto" dalam antologi Arloji [19] dan Ayat-Ayat Api [20] keindahan digambarkan dalam bentuk bunga sakura, musim semi, gerimis, dan kau. Dalam konstelasi teks ini, keindahan menjadi satu kesatuan yang tidak dipisahkan.

\section{$/ 1 /$}

segala yang mendidih dalam kepala

tidak nyata, kecuali sakura

dan kau -tentu saja

$12 /$

gerimis musim semi $\cdots$

Puisi tersebut menunjukkan konsep keindahan dalam lingkup harmonisasi alam, yakni: musim semi, gerimis, sakura, dan tentu saja kau.

Pada puisi "Lirik Untuk Lagu Pop" dalam antologi Perahu Kertas [15] dan Hujan Bulan Juni [16] keseimbangan digambarkan dengan diksi hutan, gerimis, butir air, mawar, suara, burung, gugur, kabut, dan anggrek. Keinginan untuk hidup di dalam alam (hutan) adalah bagian dalam upaya menyeimbangkan kosmos (mikro dan makro) maka yang terjadi adalah kebahagiaan untuk manusia.

jangan pejamkan matamu: aku ingin tinggal di hutan yang 
gerimis - pandangmu adalah seru butir air

tergelincir dari duri mawar (begitu nyaring!); suaramu adalah

sertap bulu burung yang gugur (begitu hening!)

Hutan yang digambarkan sebagai tempat yang penuh ketenangan dan keheningan menambah keindahan sehingga kalimat "Jangan pejamkan matamu" menjadai kalimat perintah untuk tetap dalam keindahan ini.

Antologi Mata Jendela [21] yang di dalamnya memuat puisi "Honolulu Zoo" [21] keindahan diwujudkan dengan diksi matahari, gerimis, payung, hijau, rumput, merpati, dan bernyanyi. Hal senada dengan puisi "Gadis Kecil" dalam antologi Mata Jendela [21] yang menggambarkan keindahan dengan diksi gadis kecil, gerimis, padang, pohon, dan burung. Diksi-diksi tersebut memanfaatkan kekuatan pada diksi-diksi alam seperti gerimis, pohon, burung, dan padang yang disandingkan dengan diksi kita dan gadis kecil sebagai bagian dari kode-kode simbolik keseimbangan kosmos jagad cilik dan jagad gedhe.

sewaktu seratus merpati tiba-tiba bernyanyi

di sekeliling kita, ada yang terasa gerimis jauh di dalam

[21]

ada gadis kecil diseberangkan gerimis di tangan kanannya bergoyang payung

[21]

Harmonisasi yang melibatkan alam dan manusia menjadi bagian yang tidak terpisahkan sehingga keindahan akan terwujud. Pada puisi "Ia Tak Pernah" dalam antologi Arloji [19] dan Ayat-Ayat Api [20]

Keseimbangan antara ia, pohon, burung, api, menerjemahkan, dan berjanji adalah inti dari keseimbangan ini.

ia tak pernah berjanji kepada pohon untuk menerjemahkan burung

menjadi api

ia tak pernah berjanji kepada burung untuk menyihir api

menjadi pohon

ia tak pernah berjanji kepada api untuk mengembalikan pohon

kepada burung

[19]

Puisi yang ditulis dalam bentuk distichon ini menggambarkan bagaimana kesimbangan antara manusia dan alam. Keseimbangan antara manusia (ia) dan alam (pohon, burung, dan api) harus senantiasa dijaga. Hal ini disebabkan kerusakan atas keseimbangan ini tidak dapat dibayangkan dan tentu saja akan merugikan manusia dan alam itu sendiri.

\section{Cinta Kepada Tuhan}

Cinta kepada Tuhan dapat ditunjukkan dengan konsep yang paling sederhana. Tuhan yang direpresentasi sebagai Sang Pencinta mengharuskan manusia menjelma dalam kecintaan kepada Tuhan, tidak terikat dan terkait dengan materi dunia atau keduniaan apa pun. Kecintaannya menjelma menjadi apa pun sampai pada akhir harus menjelma menjadi apa pun yang dicintainya, seperti pada puisi "Sajak-Sajak Kecil Tentang Cinta"

/3/

mencintai-Mu

harus menjelma aku

[19]

Konsep kecintaan yang mengusung cinta tanpa pamrih, tulus, dan sederhana menjadi konsep yang ditunjukkan untuk mengenal Tuhan. Hal ini disandarkan pada argumentasi bahwa Tuhan adalah Pencipta yang memiliki sifat mencintai tanpa pamrih, tulus, dan sederhana, dalam terminologi Islam dikenal dengan istilah Arrahman Arrahim. Pada puisi "Aku Ingin" dalam antologi Hujan Bulan Juni [16] konsep tersebut digambarkan dalam 2 distichon dengan rima yang sangat teratur.

aku ingin mencintaimu dengan sederhana: dengan kata yang tak sempat diucapkan kayu kepada api yang menjadikannya abu

aku ingin mencintaimu dengan sederhana: dengan isyarat yang tak sempat disampaikan awan kepada hujan yang menjadikannya tiada

[16]

Puisi tersebut mengenalkan konsep "cinta sederhana", yakni cinta yang tanpa pamrih, apa adanya, dan berusaha mengikuti konsep cinta Tuhan atas makhluknya, yang oleh Fromm [10] disebut art of life, yakni cinta manusia kepada 
manusia, manusia kepada alam, dan cinta manusia kepada Tuhan. Diksi-diksi yang digunakan dalam mengungkap konsep ini adalah: kayu, api, dan abu; serta diksi awan, hujan, dan tiada.

Cinta yang sederhana digambarkan dalam bentuk metafora kayu yang rela dibakar api, walaupun pada akhirnya kayu akan habis dan menjadi abu. Akan tetapi, hal tersebut tidak dipermasalahkan karena bukan menjadi abunya, melainkan apa yang terjadi ketika kayu tulus mencintai api, yakni hadirnya cahaya. Begitu pun cinta awan dan hujan, walaupun pada akhirnya keduanya menjadi tiada. Konsep-konsep cinta seperti ini yang menjadi bagian penting dalam menghadirkan cinta kepada Tuhan dalam bentuk yang paling tinggi.

Puisi "Akulah Si Telaga" yang ditulis dalam antologi Sihir Hujan [14], Perahu Kertas [15], dan Mata Jendela [21]. Puisi ini menggambarkan hubungan yang tidak terpisah antara telaga dan perahu.

akulah si telaga: berlayarlah di atasnya; berlayarlah menyibakkan riak-riak kecil yang menggerakkan

bunga-bunga padma;

berlayarlah sambil memandang harumnya cahaya; sesampai di seberang sana, tinggalkan begitu saja perahumu

biar aku yang menjaganya

Puisi tersebut menggambarkan proses yang akan dilalui seseorang dalam bersatu dengan Tuhannya, yakni berlayar ke seberang. Berlayar menjadi jalan bagi seseorang untuk mengenal Tuhannya. Oleh karena direpresentasi sebagai sebuah perjalanan, maka berlayar akan menghadapi cobaan hingga menemukan tujuan.

Puisi "Suara" dalam antologi Mata Jendela [21] terdapat kalimat yang diulang "Aku merapat padaMu", kalimat ini diulang 2 kali sebagai bentuk yang penting dalam puisi ini. Kalimat tersebut terdapat pada bait 1 dan bait 3 .

$\mathrm{Mu}$.

Kau takut, tanya-Mu. Aku merapat pada-

Suara siapa gerangan telah terucap lewat mulut serta dua belah mataku.

[21]
Frekeunsi kalimat "Aku merapat pada-Mu" menjadi penting karena menunjukkan kesadaran akan Tuhan dan kelemahan manusia. Kesadaran pengharapan akan Tuhan tercermin dalam diksi Mu dan Engkau. Pada puisi "Sajak Telur" dalam antologi Perahu Kertas [15] yang ditulis dengan judul puisi "Telur, 2" dalam antologi Hujan Bulan Juni [16] menunjukkan pengharapan kepada Tuhan dan ini adalah bentuk manunggal karena ada pengharapan yang disertai kerelaan dan keridaan.

\section{dalam setiap}

dalam setiap telur semoga ada burung

burung semoga ada engkau dalam setiap engkau semoga ada

yang senantiasa terbang menembus silau matahari memecah

udara dingin memuncak ke lengkung langit

menukik

melintas sungai

[15]

Harapan dalam terminologi tasawuf seringkali disandingkan dengan takut, yakni raja` dan khauf (berharap dan takut). Puisi tersebut menunjukkan harapan dengan mengulang kata "semoga" yan diulang 3 kali, semoga dapat dimaknai sebagai harapan, mudah-mudahan, moga-moga. Harapan merupakan konsep pengenalan akan Tuhan dan keseimbangan kosmos yang hakiki. Menurut $\mathrm{Al}$ Ghazali [22] harapan yang dijelaskan Nata [22] harapan memiliki ciri, yakni: cinta kepada apa yang diharapkannya; takut bila harapannya hilang; dan berusaha untuk mencapainya. Harapan ini ditunjukkan dalam puisi tersebut dengan mengulang kata "semoga".

Harapan yang disandingkan dengan khawatir sebetulnya melahirkan kedekatan dan kedekatan mewujudkan rasa cinta. Konsep ini pada puisi "Tentu. Kau Boleh" dalam antologi Arloji [19] dan Ayat-Ayat Api [20] disajikan pada bait

Sampai huruf terakhir

sajak ini. Kau-lah yang harus

bertanggung jawab

atas air mataku.

[19]

Pronomina Kau menunjuk kepada Tuhan, hal ini sesuai dengan pronomina Kau pada larik sebelumnya dalam puisi ini, seperti: /Kau boleh saja masuk, masih ada ruang di sela-sela butir darahku/. Argumentasi pada pernyataan ini adalah, pertama penggunaan huruf kapital, kedua Tuhan dalam kepercayaan masyarakat Nusantara adalah 
sangat dekat, bahkan dalam terminologi Islam, Tuhan lebih dekat dari urat leher. Kedekatan Tuhan dengan manusia dimetaforakan berosmosis dalam butir darah dan masuk ke dalam jantung. Pada puisi "Garis" dalam antologi Sihir Hujan [14] dan AyatAyat Api [20] kedekatan ditandai dengan diksi warna, hitam, keemasan, musim, dan cahaya. Diksi-diksi tersebut menyiratkan konsep kedekatan yang sudah dijelaskan.

Diksi pintu dalam konsep kedekatan ini direpresantikan dalam puisi "Pintu" dalam antologi Kolam [17] diksi pagi dan malam menjadi metafora yang menggambarkan jalan untuk melewati pintu.

kita disilakan

Pagi dikaruniai begitu banyak pintu dan

masuk melewatinya kapan saja.

Malam diberkahi begitu banyak gerbang

dan kita digoda

untuk membukanya dan keluar agar bisa ke Sana

Tidak diperlukan ketukan

Tidak diperlukan kunci

Sungguh, tidak diperlukan selamat datang

atau selamat

Tinggal.

Pintu menjadi diksi yang penting sebagai sebuah jalan menuju ke Sana (dengan huruf kapital) yang tentu saja menunjuk sebuah nama tempat, nama orang, atau Tuhan. Kedekatan digambarkan hal yang bersifat formalitas, seperti ketukan pintu atau ucapan selamat. Dengan demikian, kemanunggalan ditunjukkan pada larik /Tidak diperlukan ketukan, Tidak diperlukan kunci/ adalah kode simbolik yang merepresentasi bahwa gerbang dan pintu sudah sangat terbuka, sudah merupakan milik sendiri.

\section{KESIMPULAN}

Berdasarkan pembahasan tersebut, konsep cinta direpresentasi puisi-puisi karya Sapardi Djoko Damono ke dalam klasifikasi yang dikemukakan oleh Erich Fromm. Konsep cinta dapat ditemukan dalam struktur puisi, terutama tema dan majas yang menjadi bagian dari tanda-tanda yang dikemukakan oleh Carles Sanders Pierce. Konsep trilingual ikon, indeks, dan simbol berkelindan dalam diksi-diksi puisi sehingga mengarah kepada konsep cinta tersebut. Sesuai klasifikasi yang telah dikemukakan, cinta kepada manusia dapat ditemukan pada puisi-puisi yang memiliki diksi manusia pertama, Adam dan Hawa. Diksi ini kemudian dikerangkai dengan kode simbolik taman yang bermakna Surga. Adam dan Hawa adalah representasi cinta antarmanusia yang diajarkan langsung oleh Tuhan, Adam yang diciptakan dari tanah dan Hawa yang diwujudkan dari tulang rusuk Adam adalah bukti bahwa cinta adalah kedekatan dan karunia Tuhan. Konsep cinta kepada alam memuat hal-hal yang berkaitan dengan keindahan alam. Hal ini menunjukkan bahwa alam harus dijaga karena bagian dari kehidupan manusia. konsep cinta kepada Tuhan harus dimaknai sebagai kesederhanaan hakiki, tidak berlebihan. Tuhan adalah Yang Maha Mencinta, maka manusia sudah selayaknya manusia juga menjadi seorang pencinta bagi sesamanya. Cinta kepada Tuhan adalah bagian dari kesadaran akan posisi manusia sebagai makhluk yang lemah sehingga dengan mencintai Tuhan manusia diajarkan untuk berserah diri kepadaNya. Berdasarkan penjelasan tersebut, puisipuisi karya Sapardi Djoko Damono yang membahas konsep cinta ini merupakan bagian dari pembelajarana akan kesadaran manusia sebagai makhluk sosial dan makhluk individu yang selalu terkait dengan diri, alam, dan Tuhan.

\section{REFERENSI}

[1] R. A. Qadri, "Sapardi dan Tanda: Telaah Semiotik atas Kumpulan Puisi Kolam," in Dari Zaman Citra ke Metafiksi: Bunga Rampai Telaah Sastra DKJ, Z. Hae, Ed., ed Jakarta: Kepustakaan Populer Gramedia, 2010, pp. 171-194.

[2] H. Isnaini, "Representasi Ideologi Jawa pada Puisi-Puisi Karya Sapardi Djoko Damono," Pena: Jurnal Pendidikan Bahasa dan Sastra, vol. Vol. 10 No. 1 Juli 2020, pp. 24-47, 2020.

[3] H. Isnaini, A. Priyatna, L. M. Rahayu, and M. Adji, "Konsep Manunggaling Kawula Gusti Pada Puisi-Puisi Sapardi Djoko Damono," Jurnal Ide Bahasa, vol. Vol. 1 No. 2, pp. 115128, Desember 20192019.

[4] E. D. Hirsch, "Keabsahan Sebuah Interpretasi," in Hidup Matinya Sang Pengarang, T. Heraty, Ed., ed Jakarta: Yayasan Obor Indonesia, 2000, pp. 58-74.

[5] J. Piaget, Strukturalisme. Jakarta: Yayasan Obor Indonesia, 1995.

[6] S. Sabbah and P. Ayuningtyas, "Pemahaman Identitas dan Toleransi Keberagaman Budaya Mahasiswa Sastra Inggris UAI Melalui Puisi Multikultural Kesusasteraan Inggris: Sebuah Kajian Multikulturalisme," Al-Azhar Indonesia 
Seri Humaniora, vol. Vol. 4, No. 2 September 2017, pp. 94-103, 2017.

[7] H. J. Waluyo, Teori dan Apresiasi Puisi. Jakarta: Erlangga, 1987.

[8] N. A. Ariefa, "Makna Puisi "Kotoba" Karya Tanikawa Shuntaro: Analisis Semiotika Riffaterre," Al-Azhar Indonesia Seri Humaniora, vol. Vol. 3, No. 2 September 2015, pp. 125-136, 2015.

[9] S. Maharani, Filsafat Cinta. Yogyakarta: Garasi, 2016.

[10] E. Fromm, The Art of Loving. New York: Harper \& Row, 1956.

[11] A. v. Zoest, Semiotika. Jakarta: Yayasan Sumber Agung, 1993.

[12] S. D. Damono, DukaMu Abadi. Jakarta: Pustaka Jaya, 1969.

[13] S. D. Damono, Mata Pisau. Jakarta: Balai Pustaka, 1974.

[14] S. D. Damono, Sihir Hujan. Kuala Lumpur: Dewan Bahasa dan Pustaka, 1984.
[15] S. D. Damono, Perahu Kertas. Jakarta: Balai Pustaka, 1983.

[16] S. D. Damono, Hujan Bulan Juni. Jakarta: Gramedia-Grasindo, 1994.

[17] S. D. Damono, Kolam. Jakarta: Editum, 2009.

[18] M. S. Mahayana, Kitab Kritik Sastra. Jakarta: Yayasan Pustaka Obor Indonesia, 2015.

[19] S. D. Damono, Arloji. Jakarta: Yayasan Puisi, 1998.

[20] S. D. Damono, Ayat-Ayat Api. Jakarta: Pustaka Firdaus, 2000.

[21] S. D. Damono, Mata Jendela. Magelang: Indonesia Tera, 2001.

[22] A. Nata, Akhlak Tasawuf, . Jakarta: Grafindo, 2000. 